\title{
TUTELA PENAL AMBIENTAL À LUZ DA SOCIEDADE DE RISCO DE ULRICH BECK
}

\section{ELLEN GALLIANO DE BARROS}

Mestranda em Direito Empresarial e Cidadania - Centro Universitário Curitiba UNICURITIBA. Curitiba - PR. email: ellengalliano94@gmail.com

\section{FABIO ANDRÉ GUARAGNI}

Professor Orientador - Centro Universitário Curitiba - UNICURITIBA. Curitiba - PR. email: guaragni@mppr.mp.br

\section{RESUMO}

O presente estudo objetiva analisar a relevância da intervenção do Direito Penal na proteção efetiva do meio ambiente, sob a óptica da "Sociedade de Risco", conceituada pelo sociólogo alemão Ulrich Beck. Posto isto, destaca-se, inicialmente, as particularidades de cada sociedade, em dado momento histórico, descritas pelo autor, respectivamente: sociedade pré-industrial; modernidade clássica; e sociedade de risco. A primeira fase caracterizou-se pela convivência integrada entre homem e natureza, produção artesanal e perigos de danos naturais, justificados pelo misticismo e divindades. Após a ocorrência da "Dupla Revolução", por efeito da Revolução Francesa (ideais iluministas) e da Revolução Industrial (transformação socioeconômica), surge a segunda sociedade, marcada pela prevalência da racionalidade antropocêntrica e científica, pela dissociação entre indivíduo e meio ambiente, divisão de classes e, sobretudo, pela industrialização em larga escala, mediante a união entre avanço tecnológico e exploração intensa do homem e de recursos ambientais, os quais eram necessários à lucratividade e à qualidade de vida. Percebe-se, de imediato, que os riscos ("antecipação da catástrofe") deixaram de ser 


\section{Personalidade Acadêmica Homenageada:}

Raymundo Juliano Feitosa (Universidade Federal do Rio Grande do Norte - UFRN)

apenas naturais e tornaram-se concretos, previsíveis e quantificados, diante da decisão humana pelo progresso financeiro. Conforme as lições de Beck, a recente sociedade se estrutura por meio do elemento risco, este decorrente do avanço de maquinários, do vilipendiamento do ecossistema, da superprodução e do consumismo, que criaram novos perigos de prejuízos mundiais e que refletem contra a própria humanidade, até mesmo seus criadores ("efeito boomerang"). A preocupação recai sobre o equilíbrio ecológico e a vida das gerações futuras, considerando o risco ilimitado, incalculável, transfronteiriço e que ultrapassa o controle estatal e científico, e mais, embora seja socialmente tolerável, dada a tecnologia avançada que propicia melhores condições existenciais, acarreta a angústia de novas destruições. Ante o descompasso entre o sistema social e o meio natural (crise ambiental), proveniente da degradação promovida pelo homem, aliada à falência dos órgãos estatais de controle e à denominada "irresponsabilidade organizada" (ocultação da origem e das consequências do risco da população pelas elites políticas e econômicas), a Constituição, amparada pelo modelo de Estado Democrático de Direito, incluiu o meio ambiente ecologicamente equilibrado como direito fundamental difuso, de terceira geração, em seu art. 225, caput. Mais ainda, visando assegurar, efetivamente, o ecossistema, abarcou no $3^{\circ}{ }^{\circ}$, daquele artigo, a tipificação de condutas antiecológicas (cláusulas expressas de criminalização). Com o mandamento constitucional, o Direito Penal sofreu impactos diretos, especialmente um expansionismo dogmático, para além da proteção patrimonial e da individualização de bens jurídicos (viés clássico), o que resultou na dificuldade em tutelar o bem jurídico supraindividual, à vista da realidade complexa, incerta e heterogênea. A nova dimensão penal pretende garantir o bem-estar intergeracional através dos crimes de perigo abstrato (prescindibilidade probatória do perigo) previstos na Lei nº 9.605/1998, contudo, a doutrina aponta alguns obstáculos na construção de enunciados normativos, que inviabilizam a defesa concreta do ambiente natural. Os desajustes seriam: a dependência do Direito Penal da seara administrativa; a utilização de conceitos indeterminados; o excesso de normas penais em branco; a violação de princípios penais de ordem constitucional e postulados político-criminais; o exagero da tutela criminal; os delitos de mera desobediência e de perigo abstrato; e a 
Personalidade Acadêmica Homenageada:

Raymundo Juliano Feitosa (Universidade Federal do Rio Grande do Norte - UFRN)

responsabilidade penal da pessoa jurídica. Todavia, apesar da problemática, é indubitável a necessidade da intervenção do Direto Criminal na área ecológica, de cunho interdisciplinar e com princípios coletivos de contenção, sem negligenciar a "modernidade reflexiva", a fim de constituir o tipo adequado e uma política forte de redução de injustos ambientais. Cumpre, também, atualizar o conceito analítico de crime, da imputação subjetiva do evento, da culpabilidade e das teorias da pena. Para esta pesquisa foi utilizado o método dedutivo-indutivo, com suporte legal e doutrinário.

PALAVRAS-CHAVE: Sociedade de Risco; Sustentabilidade Ambiental; Direito Penal.

\section{REFERÊNCIAS}

AGRIPA, Alexandre Faria. A dinâmica da sociedade de risco segundo Antony Giddens e Ulrich Beck. v. 15, n. 30, jul-dez. Florianópolis: Geosul, 2000.

BECK, Ulrich. Ecological Enlightenment: essays on the politics of the risk society. New York: Humanity Books, 1995.

BECK, Ulrich. La sociedade del riesgo global: amor, violência y guerra. 2.ed. Madrid: Siglo, XXI, 2006.

BECK, Ulrich. World at risk. Cambridge: Polity Press, 2009.

BECK, Ulrich. Sociedade de Risco: Rumo a uma nova modernidade. 2.ed. São Paulo: Editora 34, 2011.

BITENCOURT, Cézar Roberto. Manual de direito penal. Parte geral. 6.ed. v.1. São Paulo: Saraiva, 2000.

BOFF, Leonardo. Sustentabilidade: O que é - o que não é. Rio de Janeiro: Vozes, 2012.

BUGALHO, Nelson Roberto. Sociedade de Risco e Intervenção do Direito Penal na proteção do ambiente. v. 6, jan. São Paulo: Ciências Penais, 2007.

CRETELLA JÚNIOR, José. Comentários à Constituição brasileira de 1988. 2. ed. v. 8. Rio de Janeiro: Forense Universitária, 1993.

FERREIRA FILHO, Manoel Gonçalves. Comentários à Constituição brasileira de 1988. v. 4. São Paulo: Editora Saraiva, 1995. 
Personalidade Acadêmica Homenageada:

Raymundo Juliano Feitosa (Universidade Federal do Rio Grande do Norte - UFRN)

FOLLONI, André. Ciência do direito tributário no Brasil: crítica e perspectivas a partir de José Souto Maior Borges. São Paulo: Saraiva, 2013.

GOLDBLATT, David. Teoria social e ambiente. Lisboa: Piaget, 1996.

GOMES, Luiz Flávio; BIANCHINI, Alice. O Direito Penal na Era da Globalização. São Paulo: Editora Revista dos Tribunais, 2002.

GUARAGNI, Fábio André. Responsabilidade Penal do ente coletivo: Pilastras PolíticoCriminais derivadas das noções de Sociedade de Risco e Alteridade. In: Aspectos contemporâneos da responsabilidade penal da pessoa jurídica. v. 2. São Paulo: Federação do Comércio de Bens, Serviços e Turismo do Estado de São Paulo, 2014.

HOBSBAWN, Eric. A era das revoluções: 1789 - 1848. 25 ed. São Paulo: Editora Paz e Terra, 2010.

ROCHA, Renata Rodrigues de Castro; ROCHA, Suyene Monteiro da. O conceito material de bem jurídico ambiental: Uma visão ontológica do meio ambiente numa perspectiva interdisciplinar. v. 02, № 43. Curitiba: Revista Jurídica - UNICURITIBA, 2016.

RUTTE, Israel; KOZICKI, Katya; RIOS, Rodrigo Sánchez. Sociedade de risco, recrudescimento da criminalidade e o crime de perigo abstrato. 2013. 149 p. Dissertação (Mestrado) - Pontifícia Universidade Católica do Paraná, Curitiba, 2013. Disponível em: http://www.biblioteca.pucpr.br/tede/tde_busca/arquivo.php?codArquivo=2855. Acesso em: 02 mai. 2019.

SANTOS, André Leonardo Copetti; ANDRADE, Roberta Lofrano. Sociedade do Risco e os crimes contra o meio ambiente. ano XX, n. 35, jan-jun. Rio Grande do Sul: Direito em Debate - Revista do Departamento de Ciências Jurídicas e Sociais da Unijuí, 2011.

TAVAROLO, Sérgio Barreira de Faria. Movimento ambientalista e modernidade: sociabilidade, risco e moral. São Paulo: Annablume/Fapesp, 2001.

TEIXEIRA, Samantha Ribas; FERREIRA, Heline Sivini. O direito material fundamental à educação ambiental no contexto da sociedade de risco. 2014. 169 f. Dissertação (Mestrado) - Pontifícia Universidade Católica do Paraná, Curitiba, 2014. Disponível em:

http://www.biblioteca.pucpr.br/tede/tde_busca/arquivo.php?codArquivo=2866. Acesso em: 02 mai. 2019. 